\title{
Adsorption capacity of phenolic compounds onto cellulose and xylan
}

\author{
Telma dos Santos COSTA ${ }^{1}$, Hervé ROGEZ ${ }^{2}$, Rosinelson da Silva PENA ${ }^{2 *}$
}

\begin{abstract}
The interaction between three phenolic compounds (catechin, caffeic acid and ferulic acid) onto two dietary fibres (cellulose and xylan) has been evaluated to inquire possible interferences on the biodisponibility of phenolic compounds. The adsorption kinetics were performed using solutions containing $100 \mathrm{mg} / \mathrm{L}$ of phenolic compounds during a contact time ranging between 10 and 120 minutes at $\mathrm{pH} 2.0,4.5$, and 7.0. After the kinetics, isotherms were obtained using phenolic compounds concentration ranging between 10 and $80 \mathrm{mg} / \mathrm{L}$ during 60 minutes, at $\mathrm{pH} 2.0$ and 7.0 and temperature of $36^{\circ} \mathrm{C}$. Results indicate that adsorbed quantities mainly changed in function of $\mathrm{pH}$, however the maximum adsorption was only of $0.978 \mathrm{mg}$ of caffeic acid/g of xylan at $\mathrm{pH} 2$ and after $60 \mathrm{~min}$. Redlich-Peterson model were able to predict the adsorption isotherms of all phenolic compounds onto cellulose, except for caffeic acid at pH 7.0. The low adsorption capacities observed suggest that both dietary fibres are unable to compromise the biodisponibility of phenolic compounds, especially in the small intestine, where they are partially absorbed.
\end{abstract}

Keywords: cellulose; xylan; adsorption; phenolic compounds; isotherm; in vitro tests.

Practical application: Adsorption of common phenolic compounds onto cellulose and xylan was firstly studied.

\section{Introduction}

Interest in dietary fibres (DFs) has grown, due to their benefits for health. Such fibres reduce the risk of developing medical disorders as obesity, hypertension, constipation, type II diabetes and hyperlipidemia (Fietz \& Salgado, 1999; Bernaud \& Rodrigues, 2013). However, some fibres reduce the bioavailability of minerals, other nutrients and drugs by interacting with these additional dietary components (Watanabe et al., 2006; Oliveira et al., 2014).

DFs are a complex of water-soluble and water-insoluble fibres (Turley et al., 1991). The amounts and types of fibres in the diet can influence the levels of macronutrient hydrolysis and absorption by interfering with enzymatic activities in the small intestine (Anderson et al., 2009). Cationic exchange is one action of these fibres that can occur at physiological $\mathrm{pH}$ when fibre-associated phytates and phenols form insoluble compounds with minerals, which reduce the intestinal absorption of these micronutrients (Brune et al., 1989).

The principal DFs are the polysaccharides cellulose, hemicellulose, pectins, mucilages, fructooligosaccharides, inulin, resistant starch, and the lignin, which is a complex polymer formed from three monolignol monomers (Amaral et al., 2008). The sources of DFs are fruits, vegetables, legumes, roots, tubers, nuts and grains (Marlett, 1992; Tungland \& Meyer, 2002).

Phenolic compounds (PCs) have been extensively studied due to their antioxidant properties and strong influence on the food quality (Augusto et al., 2014). These compounds include a wide variety of molecules, like phenolic acids, the simplest ones, consisting in a $\mathrm{C} 6-\mathrm{C} 1$ or $\mathrm{C} 6-\mathrm{C} 3$ structure, the flavonoids, which are the most abundant and presenting a $\mathrm{C} 6-\mathrm{C} 3-\mathrm{C} 6$ structure, and the stilbenes with their C6-C2-C6 structure. The consumption of certain foods may alter the bioavailability of PCs through their direct interaction with others food components, such as proteins and polysaccharides (Manach et al., 2004; Silberberg et al., 2006; D'Archivio et al., 2010). Due to the individual benefits of PCs and DFs, the food and pharmaceutical industries have shown great interest in these bioactive compounds. However, the interaction between these substances has only scarcely been studied.

Adsorption process use to be influenced by the solution $\mathrm{pH}$ (McCabe et al., 2005). Interestingly, great variability of $\mathrm{pH}$ is observed in the gut during digestion (Hollebeeck et al., 2013). In general, the $\mathrm{pH}$ levels reported in the literature for salivary, gastric, and duodenal digestion have presented a low variation, ranging from 5.0 (Minekus et al., 1995) to 6.9 (Lebet et al., 1998) for the salivary step, from 1.1 to 2.8 for the gastric step, and from 6.3 to 7.8 for the duodenal step (Alexandropoulou et al., 2006; Hollebeeck et al., 2013).

Adsorption is a separation process that is increasingly used in the recovery, concentration, separation and purification of compounds that may have a high aggregate value. This process is characterized as one of mass transfer in which one or more compounds present in a fluid phase adhere to a solid surface (Geankoplis, 2003). Mwangi et al. (2014), Wu et al. (2014), Mekoue Nguela et al. (2015), and Strachowski \& Bystrzejewski (2015) studied the adsorption process of phenolic compounds onto different organic compounds.

${ }^{1}$ Programa de Pós-Graduação em Ciência e Tecnologia de Alimentos, Instituto de Tecnologia, Universidade Federal do Pará - UFPA, Belém, PA, Brasil

${ }^{2}$ Faculdade de Engenharia de Alimentos, Instituto de Tecnologia, Universidade Federal do Pará - UFPA, Belém, PA, Brasil

*Corresponding author: rspena@ufpa.br 
In the literature, there are diverse models that describe adsorption isotherms. The Langmuir and Freundlich equations stand out as the most frequently used equations to represent these isotherms because of their wide applicability, ease of adjustment, wide range of operating conditions (Chu et al., 2004) and ability to explain the adsorption of biological compounds (Ribeiro et al., 2002; Gao et al., 2013).

This study aimed to assess natural interaction between PCs (catechin, caffeic acid and ferulic acid) and dietary fibres (cellulose and xylan) in relation to digestion $\mathrm{pH}$ ranging from 2.0 to 7.0 and normal PCs concentration found in foods using adsorption processes.

\section{Materials and methods}

\subsection{Dietary fibres}

The DFs cellulose and xylan (Sigma, Steinhelm, Germany) were used to evaluate the PCs and DFs interaction. The choice of these fibres was based on preliminary tests of solubility of cellulose, pectin, lignin, xylan and inulin in water. Cellulose and xylan (Figure 1) were the least soluble, which allows a greater facility for separation of the fibres after adsorption processes.

\subsection{Phenolic compounds}

The following factors were used in choosing the PCs: significant occurrence in the plant kingdom, ready availability, commercial value and water solubility. Using these criteria, the following pure compounds (HPLC grade) were selected: the flavanol catechin (Fluka, Buchs, Switzerland) of the flavonoid class, and caffeic acid (Fluka) and ferulic acid (Sigma) of the phenolic acid class, cynamic acid subclass (Figure 2).

\subsection{Solvent and process conditions}

Ultrapure water was used as solvent in the adsorbent system (solute/solvent/adsorbent). Water was selected as the solvent based on human digestive physiology, and its capacity to dissolve more of the PC than the DF, which facilitated the separation of the fibres by centrifugation after adsorption process. The temperature utilized for the procedure was $36^{\circ} \mathrm{C}$ to approximate the human body temperature. The $\mathrm{pH}$ levels were 2.0 to simulate stomach chyme, 7.0 to simulate the ileum chyme and 4.5 , which is the arithmetic mean of the previous values (Hollebeeck et al., 2013).

\subsection{Adsorption kinetics}

The adsorption kinetics were determined to assess the affinity between the different DFs (adsorbent) and PCs (adsorbate), establish the best duration for the adsorbate-adsorbent interactions and determine an appropriate concentration range for the PCs solutions that were utilized to obtain the adsorption isotherms. Each PC was solubilized at the three $\mathrm{pH}$ levels using the following $0.1 \mathrm{M}$ buffers: $\mathrm{pH} 2.0(\mathrm{HCl} / \mathrm{KCl}), \mathrm{pH} 4.5\left(\mathrm{CH}_{3} \mathrm{COOH} / \mathrm{CH}_{3} \mathrm{COONa}\right)$ and pH 7.0 $\left(\mathrm{NaH}_{2} \mathrm{PO}_{4} / \mathrm{Na}_{2} \mathrm{HPO}_{4}\right)$ (Lehninger \& Nelson, 2006). The $\mathrm{PC}$ concentration in these trials was fixed at $100 \mathrm{mg} / \mathrm{L}$, which is the average concentration of these bioactive compounds in the digestive tract (Mullie et al., 2007). PCs were first solubilized in ethanol and then in buffers, with a final concentration in ethanol of $4 \%$ (v:v). The samples were subjected to an ultrasonic bath for 3 minutes. After complete solubilization, the solutions were kept away from light to avoid possible degradation. The adsorbate:adsorbent (w:v) ratio was 1:50, mimicking the ratio usually found in foods (Pereira et al., 2004).

Ten milliliters of each PC solution $(100 \mathrm{mg} / \mathrm{L})$ was added into $75 \mathrm{~mL}$ amber vials containing $50 \mathrm{mg}(0.5 \%$ mass/volume of solution) of the $\mathrm{DF}$. The vials were saturated with gaseous nitrogen, sealed and placed in a shaker at $36^{\circ} \mathrm{C}$ with mechanical shaking of $150 \mathrm{rpm}$ for 10, 20,30, 60, 90 and $120 \mathrm{~min}$. Then, the samples were centrifuged at $3,500 \mathrm{rpm}$ for $5 \mathrm{~min}$ to force sedimentation of the fibres and collect of the supernatants. The supernatants were stored in amber vials saturated with gaseous nitrogen until the PC quantification. The concentration of PC adsorbed was calculated using the difference between the concentration of PC before $\left(\mathrm{C}_{\mathrm{o}}\right)$ and after the adsorption process.

\subsection{Obtaining the adsorption isotherms}

In this step, the conditions were the same as those of the kinetics trials, except that the concentration of the phenol solution varied from 10 to $100 \mathrm{mg} / \mathrm{L}$, and the duration of contact between the PCs and the DFs was fixed at $60 \mathrm{~min}$. These conditions were established based on the adsorption kinetics. The adsorption

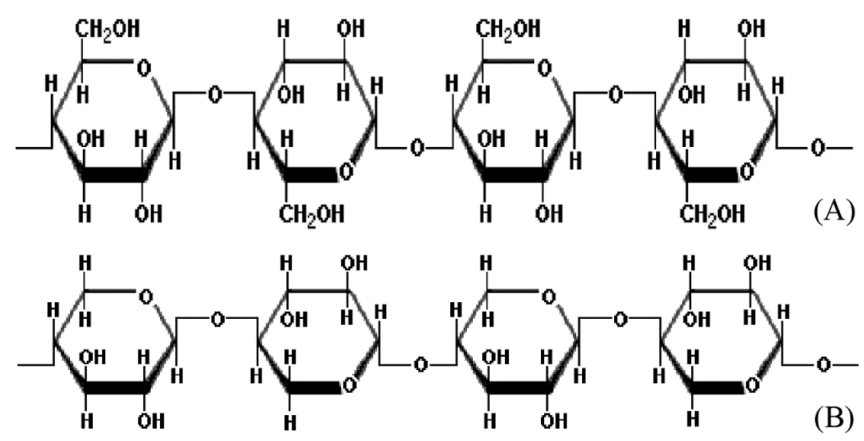

Figure 1. Chemical structures of cellulose (A) and xylan (B).<smiles>Oc1cc(O)c2c(c1)O[C@H](c1ccc(O)c(O)c1)[C@H](O)C2</smiles><smiles>O=C(O)/C=C/c1ccc(O)c(O)c1</smiles>

(B)<smiles>COc1cc(/C=C/C(=O)O)ccc1O</smiles>

Figure 2. Chemical structures of catechin (A), caffeic acid (B) and ferulic acid (C). 
isotherms were obtained for the phenols catechin, ferulic acid and caffeic acid at pH 2.0 and 7.0 in cellulose.

\subsection{Quantification of the phenolic compounds}

PCs were quantified by HPLC using a previously described methodology (Souza et al., 2008). The system and operating conditions were as follows: a Shimadzu series LC-10Avp (Tokyo, Japan) HPLC apparatus paired with an SPD-M20A diode array detector, an automatic SIL-10AF injector, a column oven at $30^{\circ} \mathrm{C}$, a precolumn Gemini analyzer with a $3.0 \times 4.0 \mathrm{~mm}$ internal diameter and a Gemini $\mathrm{C}_{18}$ column of $250 \times 4.6 \mathrm{~mm}$ internal diameter with a particle size of $5 \mu \mathrm{m}$ (Phenomenex, Torrance, $\mathrm{CA}$ ) and the Class VP chromatography data station software (Shimadzu). The elution gradient was composed of ultrapure water (solvent A) and acetonitrile (solvent B), both with $1 \%$ formic acid. The flow rate was $0.75 \mathrm{~mL} / \mathrm{min}$ with $18-27.6 \%$ of B in 6 min, 27.6- $49 \%$ of B in 2 min, $49 \%$ of B for 5 min, $49-18 \%$ of $B$ in $2 \mathrm{~min}$, and $18 \%$ of $B$ for $10 \mathrm{~min}$. All of the samples were filtered through $0.45 \mu \mathrm{m}$ membrane, and the injection volume was $20 \mu \mathrm{L}$. The PC peaks were identified by comparing the retention times of the peaks with those of standards and by sample coelution with the standards. The compounds were quantified using external calibration curves generated for each $\mathrm{pH}$ using three observations at each of five concentrations ranging from 5 to $100 \mathrm{mg} / \mathrm{L}$ (Skoog et al., 2007). For quantification of the phenols, injections to compare the area of the phenol peak with that of the standard were conducted in duplicate.

\subsection{Statistical treatment and prediction of the adsorption isotherms}

Student's t-tests with $5 \%$ level of significance were applied to compare adsorption between the different fibres and PCs. The Langmuir (Equation 1), Freundlich (Equation 2) and RedlichPeterson (Equation 3) models were fitted to the adsorption isotherms by the non-linear regression using the STATISTICA Kernel Release 7.1 software (StatSoft Inc., 2006) for Windows XP. These analyses utilized the Levenberg-Marquardt algorithm and a convergence criterion of $10^{-6}$. The fit quality of the models for the adsorption data was estimated by the coefficient of determination $\left(\mathrm{R}^{2}\right)$ and $\mathrm{p}$-values of regression.

$\mathrm{q}_{\mathrm{e}}=\frac{\mathrm{Q}_{\mathrm{M}} \mathrm{a}_{\mathrm{L}} \mathrm{C}_{\mathrm{e}}}{1+\mathrm{a}_{\mathrm{L}} \mathrm{C}_{\mathrm{e}}}=\frac{\mathrm{K}_{\mathrm{L}} \mathrm{C}_{\mathrm{e}}}{1+\mathrm{a}_{\mathrm{L}} \mathrm{C}_{\mathrm{e}}}$
$\mathrm{q}_{\mathrm{e}}=\mathrm{K}_{\mathrm{F}} \mathrm{C}_{\mathrm{e}}^{\mathrm{b}_{\mathrm{F}}}$

$\mathrm{q}_{\mathrm{e}}=\frac{\mathrm{K}_{\mathrm{R}} \times \mathrm{C}_{\mathrm{e}}}{1+\mathrm{a}_{\mathrm{R}} \times \mathrm{C}_{\mathrm{e}}^{\mathrm{b}_{\mathrm{R}}}}$

where $q_{e}$ is the adsorption capacity (mg/g adsorbent); $C_{e}$ is the concentration of the solution at equilibrium $(\mathrm{mg} / \mathrm{L}) ; Q_{M}$ is the maximum adsorption capacity $(\mathrm{mg} / \mathrm{g}) ; a_{L}$ and $a_{R}$ are the equilibrium constants of Langmuir and Redlich-Peterson equations, respectively $(\mathrm{L} / \mathrm{mg}) ; K_{L}$ is the solute adsorbability $(\mathrm{L} / \mathrm{g})$ $\left(K_{L}=a_{L} Q_{M}\right)$; and $K_{F}$ and $K_{R}(\mathrm{~L} / \mathrm{g})$ and $b_{F}$ and $b_{R}$ (dimensionless) are constants of Freundlich and Redlich-Peterson equations, respectively.

\section{Results and discussion}

\subsection{Adsorption kinetics}

Table 1 shows the adsorption data for the PCs onto cellulose at the different $\mathrm{pH}$ levels. These data show that the adsorption capacity varied with the $\mathrm{PC}$ and the $\mathrm{pH}$. For all PCs, the greatest adsorption occurred at $\mathrm{pH} 2.0$, and the maximum adsorption was $0.478 \pm 0.071,0.880 \pm 0.102$ and $0.529 \pm 0.015 \mathrm{mg} / 100 \mathrm{mg}$ of cellulose for catechin, caffeic acid and ferulic acid, respectively. Interestingly, the effect of $\mathrm{pH}$ varied among the three PCs. An increase in $\mathrm{pH}$ caused a reduction in the adsorption capacity of cellulose for ferulic acid. For caffeic acid, the adsorption decreased at a $\mathrm{pH}$ of 4.5 but showed little additional change as the $\mathrm{pH}$ was increased to 7.0. For catechin, the adsorption was minimal at the intermediate $\mathrm{pH}$ (4.5) but increased again at $\mathrm{pH}$ 7.0. The maximum adsorption indicated a greater affinity of caffeic acid for cellulose compared with ferulic acid and catechin, which adsorbed at similar levels.

Table 2 presents data on the PC adsorption onto xylan at the three $\mathrm{pH}$ levels. This $\mathrm{DF}$ has also produced adsorption results that varied with both the $\mathrm{PC}$ and the $\mathrm{pH}$. The adsorption was greatest at $\mathrm{pH} 2.0$ and reached levels of $0.642 \pm 0.023,0.978 \pm 0.060$ and $0.568 \pm 0.028 \mathrm{mg} / 100 \mathrm{mg}$ of xylan for catechin, caffeic acid and ferulic acid, respectively. Also, xylan had the greatest adsorption capacity to caffeic acid, and catechin and ferulic acid were adsorbed in similar quantities. Mwangi et al. (2014) found adsorption capacities from 0.45 to $0.88 \mathrm{mg} / 100 \mathrm{mg}$ for phenolic compounds onto quaternised maize tassels at $\mathrm{pH}$ 6.0.

Among the studied PCs, the greatest adsorption capacities of both the cellulose and the xylan fibres were observed for the

Table 1. Kinetics adsorption of phenolic compounds onto cellulose at $36{ }^{\circ} \mathrm{C}$, at different levels of $\mathrm{pH}$ and times (adsorbate:adsorbent (w:v) ratio $=1: 50)$.

\begin{tabular}{|c|c|c|c|c|c|c|c|c|c|}
\hline \multirow{2}{*}{$\begin{array}{l}\text { Time } \\
(\min )\end{array}$} & \multicolumn{9}{|c|}{ Adsorption capacity, $q_{e}(\mathrm{mg} / 100 \mathrm{mg}$ of cellulose $)$} \\
\hline & \multicolumn{3}{|c|}{ Catechin } & \multicolumn{3}{|c|}{ Caffeic acid } & \multicolumn{3}{|c|}{ Ferulic acid } \\
\hline 10 & 0.436 & 0.022 & 0.029 & 0.867 & 0.044 & 0.022 & 0.516 & 0.205 & 0.015 \\
\hline 30 & 0.370 & 0.015 & 0.197 & 0.850 & 0.042 & 0.060 & 0.529 & 0.197 & 0.040 \\
\hline 60 & 0.297 & 0.015 & 0.197 & 0.852 & 0.053 & 0.064 & 0.485 & 0.187 & 0.037 \\
\hline
\end{tabular}


Table 2. Kinetic adsorption of phenolic compounds onto xylan at $36^{\circ} \mathrm{C}$, at different levels of $\mathrm{pH}$ and different time (adsorbate:adsorbent (w:v) ratio $=1: 50)$.

\begin{tabular}{|c|c|c|c|c|c|c|c|c|c|}
\hline \multirow{3}{*}{ Time (min) } & \multicolumn{9}{|c|}{ Adsorption capacity, $q_{e}(\mathrm{mg} / 100 \mathrm{mg}$ of xilana) } \\
\hline & \multicolumn{3}{|c|}{ Catechin } & \multicolumn{3}{|c|}{ Caffeic acid } & \multicolumn{3}{|c|}{ Ferulic acid } \\
\hline & pH 2 & pH 4.5 & pH 7 & $\mathrm{pH} 2$ & pH 4.5 & pH 7 & pH 2 & $\mathrm{pH} 4.5$ & $\mathrm{pH} 7$ \\
\hline 10 & 0.642 & 0.039 & 0.191 & 0.824 & 0.011 & 0.029 & 0.524 & 0.157 & 0.010 \\
\hline 30 & 0.492 & 0.061 & 0.330 & 0.800 & 0.030 & 0.082 & 0.499 & 0.156 & 0.022 \\
\hline 60 & 0.407 & 0.059 & 0.347 & 0.978 & 0.042 & 0.048 & 0.526 & 0.158 & 0.024 \\
\hline
\end{tabular}

cinnamic acids, and the quantity adsorbed was approximately $70 \%$ greater for the caffeic acid than for the ferulic acid. The only structural difference between the two phenolic acids is the presence of an - $\mathrm{OH}$ group in $\mathrm{C} 3$ of the aromatic ring in caffeic acid and an $-\mathrm{OCH}_{3}$ group in ferulic acid (Figure 2), leading to a greater polarity for the caffeic acid (Robards et al., 1999), which would increase interaction with the surface of the cellulose and xylan through hydrogen bonds.

The adsorption behavior of the phenols in both cellulose and xylan at varying $\mathrm{pH}$ levels can be explained by the $\mathrm{pKa}$ values. Caffeic acid, ferulic acid and catechin have $\mathrm{pKa}$ values of 4.37, 4.50 and 8.64, respectively (Maegawa et al., 2007). By definition, when the $\mathrm{pH}$ of a solution is equal to the $\mathrm{pKa}$ of a compound in solution, $50 \%$ of the molecules of the solute are in an ionic state and dissociated. When the $\mathrm{pH}$ is greater than $\mathrm{pKa}$, the dissociation of the $-\mathrm{COOH}$ or $-\mathrm{OH}$ group increases and the molecular form decreases (Srivastava et al., 2006). Most phenolic acids are on a molecular form when the $\mathrm{pH}$ is less than 4 and are in the ionized form when the $\mathrm{pH}$ is greater than 4. One of the principal consequences of the ionization of phenolic acids is a major hydration (Fennema, 2000), which prevents interaction with non-ionic adsorbents, because the binding energy of the adsorbate is greater with the water than with the adsorbent. Thus, this hydration can explain the reduced adsorption capacity of caffeic and ferulic acids with increasing $\mathrm{pH}$ onto both the cellulose and xylan fibres.

The greater adsorption capacities onto DFs for the caffeic and ferulic acids at $\mathrm{pH}$ of 2.0 can also be explained by the abundance of $-\mathrm{OH}$ groups on both the phenolic acids, and the cellulose and xylan fibres. These $-\mathrm{OH}$ groups increase the probability of hydrogen bridges between the DFs and PCs. The $-\mathrm{COOH}$ acid groups would only be in a molecular form at this $\mathrm{pH}$ level, enhancing the hydrogen bonds possibilities with the non-ionic adsorbents. For the flavanol catechin, its lower affinity for the cellulose and xylan can be explained by its typical tridimensional conformation. In fact, these compounds exhibit chirality in the $\mathrm{C} 2$ and $\mathrm{C} 3$ positions of the $\mathrm{C}$ ring that greatly reduces the formation of hydrogen bonds with the polar groups of the fibres.

The PC adsorption onto both the cellulose and the xylan was low in this study compared with that of other adsorbents reported in the literature. Pompeu et al. (2010) observed adsorption capacities of 13.3, 6.3 and $11.7 \mathrm{mg} / 100 \mathrm{mg}$ of synthetic macroporous resin for catechin, and caffeic and ferulic acids, respectively. The low levels of adsorption observed in this study

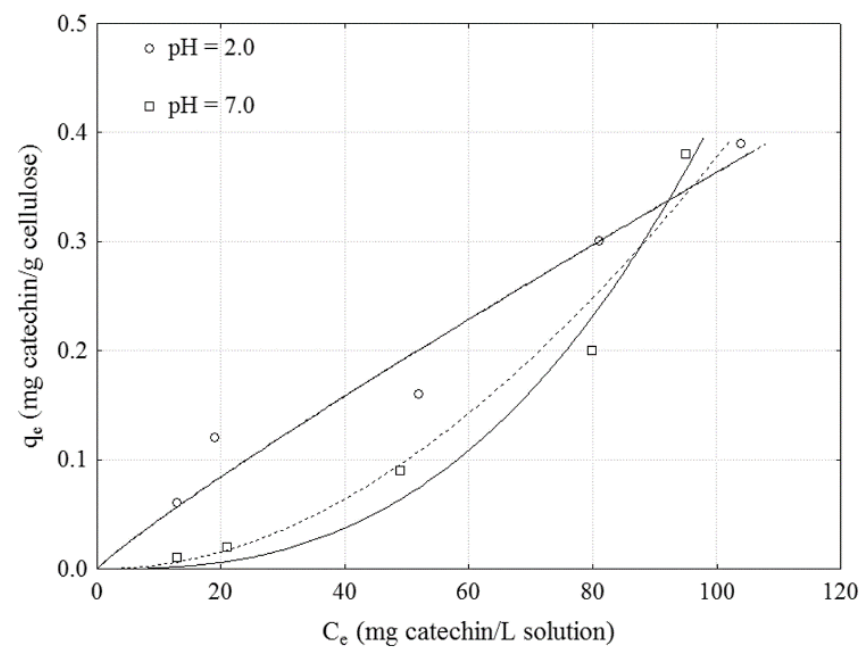

Figure 3. Adsorption isotherm of catechin onto cellulose at $\mathrm{pH} 2.0$ and 7.0: Freundlich model (continue line) and Redlich-Peterson model (dotted line).

could be attributed to the lower specific areas of the DFs compared with the synthetic resins and a greater affinity of the phenols for the water solvent than for the fibres. Microcrystalline cellulose has a specific area of $2.39 \mathrm{~m}^{2} / \mathrm{g}$ (Padilha et al., 1995), whereas this value varies between 400 and $1200 \mathrm{~m}^{2} / \mathrm{g}$ for macroporous resins (McCabe et al., 2005; Pompeu et al., 2010). Other phenols also showed superior adsorption on synthetic resins and other materials (Li et al., 2002; Bilgili, 2006; Strachowski \& Bystrzejewski, 2015).

From the adsorption kinetics data at a pH 2.0 (Tables 1 and 2), it was established for all of the combinations of the PCs and DFs studied that the greatest mass transfer of solute to the adsorbent occurred within the first minutes of contact. After 10 minutes, the mass transfer decreased significantly, which indicated saturation of the active sites of the adsorbent. Instantaneous adsorption would implicate a chemical process, which involves electrostatic forces and covalent bonds and is generally limited to the formation of a monolayer (Teixeira et al., 2001; Mwangi et al., 2014). However, the adsorption kinetics varied significantly among the phenol-fibre combinations after maximum adsorption was reached, which indicates competition between the fibres and the solvent for the PCs and, consequently, that the PC-fibre interaction was not sufficiently strong to 
confirm a chemical bond. This variation was most evident for the adsorption of catechin, which corroborates its lower affinity for the fibres.

In comparing the different two-way combinations between the three PCs and the two DFs within each of the three pH levels, there was no significant difference ( $p>0.05)$ for the adsorption of caffeic acid by cellulose compared with xylan regardless of the $\mathrm{pH}$ level, and the catechin and ferulic acid were similarly adsorbed by xylan $(\mathrm{p}>0.05)$ in the trials conducted at $\mathrm{pH} 2.0$ and 4.5. All other possible two-way combinations showed a significant difference $(\mathrm{p} \leq 0.05)$.

\subsection{Adsorption isotherms}

The adsorption isotherms of PCs onto cellulose are shown in Figures 3 and 4 for $\mathrm{pH} 2.0$ and 7.0. These figures also show lines indicating the adjusted isotherms of the Langmuir, Freundlich, and Redlich-Peterson models, whose the fitting parameters are shown in Table 3. Only the cellulose isotherms at pH 2.0 and 7.0 are presented, due to the similar adsorption behavior of xylan. According to Weber (1972), the behavior of the isotherms of caffeic (Figure 4A) and ferulic (Figure 4B) acids indicates favorable adsorption, the behavior of the catechin isotherm (Figure 3) at $\mathrm{pH} 7.0$ indicates unfavorable adsorption, and the linear behavior of the catechin isotherm at $\mathrm{pH} 2.0$ indicates an intermediate process. Some authors have observed similar behaviors by adsorption isotherms of PCs in synthetic resins (Li et al., 2002; Bilgili, 2006; Pompeu et al., 2010; Gao et al., 2013).

The coefficient of determination values $\left(\mathrm{R}^{2}\right)$ close to unity (Table 3 ) and p-values of regression lower than 0.05 indicate that the Freundlich and Redlich-Peterson models are able to predict the adsorption isotherms of catechin (Figure 3), and Langmuir and Redlich-Peterson models are able to predict the isotherms of caffeic and ferulic acids (Figure 4) onto cellulose, except for caffeic acid at $\mathrm{pH} 7.0$, for which the low adsorption contributes to high variation in the equilibrium. The Langmuir model assumes that adsorptions occur at specific homogeneous sites onto the adsorbent and is used successfully in many monolayer adsorption processes. The Freundlich model is applicable to both monolayer (chemisorption) and multilayer (physisorption) adsorption and is based on the assumption that the adsorbate adsorbs onto the heterogeneous surface of an adsorbent. The Redlich-Peterson model contains three parameters and incorporates the features of the Langmuir and the Freundlich models (Pillai et al., 2013). These characteristics justify the good fits of the Redlich-Peterson model for both the flavanol catechin as for phenolic acids.

The maximum adsorption capacity $\left(Q_{M}\right)$ of the isotherms that presented favorable adsorption (caffeic and ferulic acids) confirms a greater affinity by cellulose for caffeic acid $(0.94 \mathrm{mg} / \mathrm{g})$ than for ferulic acid $(0.69 \mathrm{mg} / \mathrm{g})$ at a $\mathrm{pH}$ of 2.0 (Table 3). The $Q_{M}$ values were well below those reported in the literature
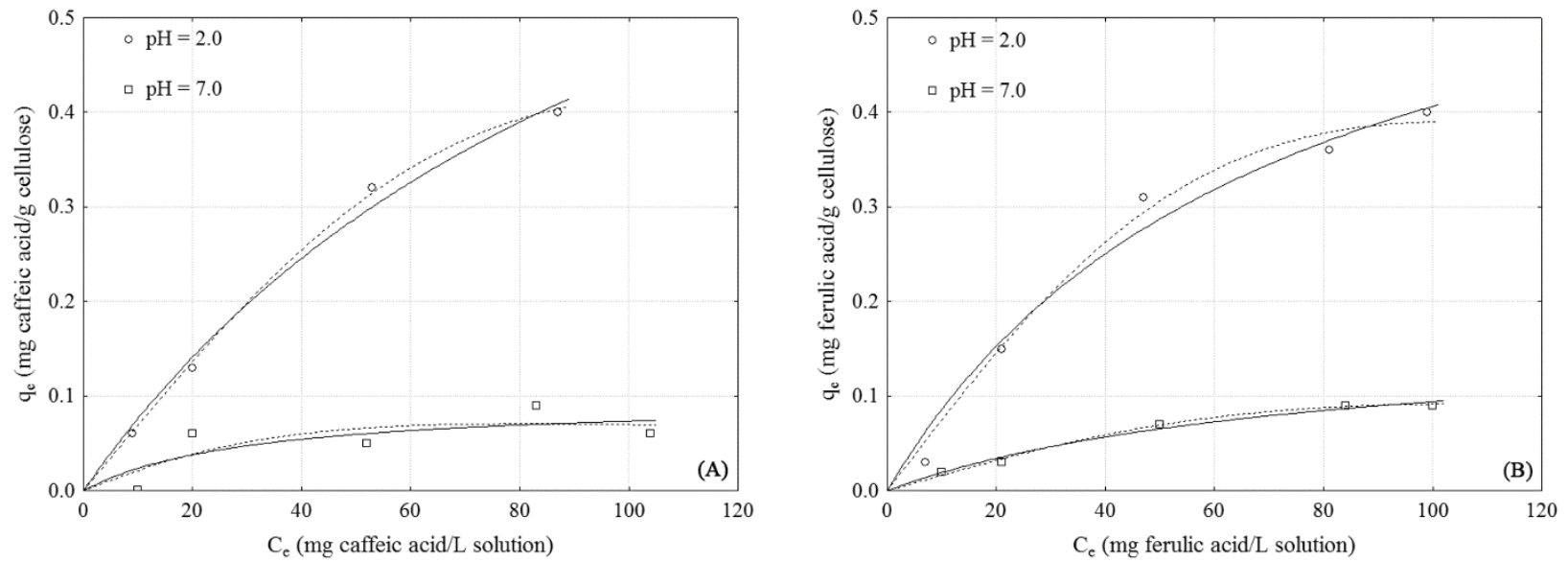

Figure 4. Adsorption isotherms of caffeic (A) and ferulic (B) acids onto cellulose at pH 2.0 and 7.0: Langmuir model (continue line) and RedlichPeterson model (dotted line).

Table 3. Parameters of mathematical modeling of adsorption isotherms by Langmuir, Freundlich and Redlich-Peterson models.

\begin{tabular}{|c|c|c|c|c|c|c|c|c|c|c|c|}
\hline \multirow{2}{*}{$\begin{array}{l}\text { Phenolic } \\
\text { compounds }\end{array}$} & \multicolumn{4}{|c|}{ Langmuir model } & \multicolumn{3}{|c|}{ Freundlich model } & \multicolumn{4}{|c|}{ Redlich-Peterson model } \\
\hline & $\begin{array}{c}Q_{M} \\
(\mathrm{mg} / \mathrm{g})\end{array}$ & $\begin{array}{c}\boldsymbol{a}_{L} \\
(\mathrm{~L} / \mathrm{mg}) \\
\end{array}$ & $\begin{array}{c}K_{L} \\
(\mathrm{~L} / \mathrm{g}) \\
\end{array}$ & $\mathbf{R}^{2}$ & $\begin{array}{c}K_{F} \\
(\mathrm{~L} / \mathrm{g}) \\
\end{array}$ & $\boldsymbol{b}_{F}$ & $\mathbf{R}^{2}$ & $\begin{array}{c}K_{R} \\
(\mathrm{~L} / \mathrm{g})\end{array}$ & $\begin{array}{c}\boldsymbol{a}_{R} \\
(\mathrm{~L} / \mathrm{mg}) \\
\end{array}$ & $b_{R}$ & $\mathbf{R}^{2}$ \\
\hline Catechin $^{\mathrm{a}}$ & 7.52 & 0.0005 & 0.0032 & 0.9498 & 0.0056 & 0.91 & 0.9536 & 0.2715 & 47.72 & 0.09 & 0.9563 \\
\hline Catequin ${ }^{\mathrm{b}}$ & 32.99 & 0.0001 & 0.0009 & 0.8256 & $2 \times 10^{-6}$ & 2.63 & 0.9770 & 0.0163 & 547.65 & -1.12 & 0.9605 \\
\hline Caffeic acid ${ }^{\mathrm{a}}$ & 0.94 & 0.0088 & 0.0083 & 0.9909 & 0.0148 & 0.75 & 0.9780 & 0.0070 & $3 \times 10^{-5}$ & 2.15 & 0.9988 \\
\hline Caffeic acid ${ }^{\mathrm{b}}$ & 0.09 & 0.0328 & 0.0031 & 0.5922 & 0.0089 & 0.46 & 0.5314 & 0.0022 & 0.0011 & 1.65 & 0.6187 \\
\hline Ferulic acid ${ }^{\mathrm{a}}$ & 0.69 & 0.0141 & 0.0098 & 0.9756 & 0.0212 & 0.65 & 0.9469 & 0.0075 & $9 \times 10^{-5}$ & 2.01 & 0.9873 \\
\hline Ferulic acid ${ }^{\mathrm{b}}$ & 0.17 & 0.0129 & 0.0022 & 0.9820 & 0.0051 & 0.64 & 0.9645 & 0.0016 & $6 \times 10^{-5}$ & 2.07 & 0.9931 \\
\hline
\end{tabular}

${ }^{\mathrm{a}} \mathrm{pH}$ 2.0. ${ }^{\mathrm{b}} \mathrm{pH}$ 7.0. $Q_{M}$ - maximum adsorption capacity. $K_{L}$ and $a_{L}-$ constants of Langmuir equation. $K_{F}$ and $b_{F}-$ constants of Freundlich equation. $\mathrm{K}_{\mathrm{R}}$, $\mathrm{a}_{\mathrm{R}}$ and $\mathrm{b}_{\mathrm{R}}-$ constants of RedlichPeterson equation. $\mathrm{R}^{2}$ - coefficient of determination. 
for the adsorption of caffeic (45.13-63.13 mg/g) and ferulic $(95.66-117.63 \mathrm{mg} / \mathrm{g})$ acids onto synthetic macroporous resins (Pompeu et al., 2010).

The $a_{L}$ values, which represent a relationship between adsorption and desorption, ranged from 0.0001 to $0.0005 \mathrm{~L} / \mathrm{mg}$ for catechin, and $0.0088-0.0338 \mathrm{~L} / \mathrm{mg}$ for caffeic and $0.0129-0.0141 \mathrm{~L} / \mathrm{mg}$ for ferulic acids. These values also confirmed the greater cellulose affinity for caffeic acid and the lower affinity shown for catechin. However, the low values of solute adsorbability $\left(K_{L}<0.01\right)$ demonstrated a low interaction between the three phenols and cellulose.

The $K_{F}$ values (Table 3), which represent the adsorption capacity by the Freundlich model, showed the same tendencies as those of the $Q_{M}$ values for the interaction between cellulose and the three PCs. Values of $b_{F}>0.45$ also confirmed the weak interactions of cellulose with the PCs, especially catechin. According to Treybal (1980) values of $b_{F}<0.1$ indicate high interaction between adsorbate and adsorbent, while values between 0.9 and 1.0 indicate low interaction in an adsorption process.

\subsection{Physiological considerations}

Direct interactions between PCs and other food components, such as bonds with proteins and polysaccharides, and direct effects, such as that of $\mathrm{pH}$, can interfere with the $\mathrm{PC}$ absorption by the gut (Silberberg et al., 2006). In relating the results obtained in this study to physiological parameters and the PC bioavailability, we conclude, based on the low levels of adsorption observed, that adsorption of catechin, caffeic acid and ferulic acid by the DFs cellulose and xylan would not compromise their absorption by the intestinal epithelial cells, where most of the phenols are known to be absorbed, especially at a $\mathrm{pH}$ close to 7.0 (Oliveira \& Bastos, 2011). However, more studies are necessary to confirm our conclusion, especially in relation to DFs, which are generally associated with polyphenols in the food matrix (Manach et al., 2004).

\section{Conclusions}

The greatest adsorption of catechin, and caffeic and ferulic acids by cellulose and xylan occurred at a $\mathrm{pH}$ of 2.0. Overall, maximum adsorption for the PCs onto DFs occurred after them had been in contact for only 10 minutes. The Langmuir and Redlich-Peterson models were able to predict the isotherms of caffeic and ferulic acids, while the Freundlich and RedlichPeterson models showed efficient to describe the isotherms of catechin onto cellulose. The low adsorptions of catechin, and caffeic and ferulic acids onto cellulose and xylan suggest that these interactions are too weak to compromise the biodisponibility of these substances, especially in the small intestine, where they are partially absorbed.

\section{Acknowledgements}

The authors would like to thank CAPES (Coordenação de Aperfeiçoamento de Pessoal de Nível Superior) and CNPq (Conselho Nacional de Desenvolvimento Científico e Tecnológico) for financial support.

\section{References}

Alexandropoulou, I., Komaitis, M., \& Kapsokefalou, M. (2006). Effects of iron, ascorbate, meat and casein on the antioxidant capacity of green tea under conditions of in vitro digestion. Food Chemistry, 94(3), 359-365. http://dx.doi.org/10.1016/j.foodchem.2004.11.023.

Amaral, A. C. M., Magnoni, D., \& Cukier, C. (2008). Fibra alimentar. São Paulo: Instituto de Metabolismo e Nutrição.

Anderson, J. W., Baird, P., Davis, R. H., Jr., Ferreri, S., Knudtson, M., Koraym, A., Waters, V., \& Williams, C. L. (2009). Health benefits of dietary fiber. Nutrition Reviews, 67(4), 188-205. http://dx.doi. org/10.1111/j.1753-4887.2009.00189.x. PMid:19335713.

Augusto, T. R., Salinas, E. S. S., Alencar, S. M., D’arce, M. A. B. R., Camargo, A. C., \& Vieira, T. M. F. S. (2014). Phenolic compounds and antioxidant activity of hydroalcoholic extracts of wild and cultivated murtilla (Ugni molinae Turcz.). Food Science and Technology (Campinas), 34(4), 667-679. http://dx.doi.org/10.1590/1678-457X.6393.

Bernaud, F. S. R., \& Rodrigues, T. C. (2013). Fibra alimentar--ingestão adequada e efeitos sobre a saúde do metabolismo. Arquivos Brasileiros de Endocrinologia e Metabologia, 57(6), 397-405. http://dx.doi. org/10.1590/S0004-27302013000600001. PMid:24030179.

Bilgili, M. S. (2006). Adsorption of 4-chlorophenol from aqueous solutions by xad- 4 resin: isotherm, kinetic, and thermodynamic analysis. Journal of Hazardous Materials, 137(1), 157-164. http:// dx.doi.org/10.1016/j.jhazmat.2006.01.005. PMid:16487655.

Brune, M., Rossander, L., \& Hallberg, L. (1989). Iron absorption and phenolic compounds: importance of different phenolic structures. European Journal of Clinical Nutrition, 43(8), 547-557. PMid:2598894.

Chu, B. S., Baharin, B. S., Che Man, Y. B., \& Quek, S. Y. (2004). Separation of vitamin e from palm fatty acid distillate using silica: I. Equilibrium of batch adsorption. Journal of Food Engineering, 62(1), 97-103. http://dx.doi.org/10.1016/S0260-8774(03)00196-1.

D’Archivio, M., Filesi, C., Varì, R., Scazzocchio, B., \& Masella, R. (2010). Bioavailability of the polyphenols: status and controversies. International Journal of Molecular Sciences, 11(4), 1321-1342. http:// dx.doi.org/10.3390/ijms11041321. PMid:20480022.

Fennema, O. (2000). Química de los alimentos (3rd ed.). Zaragoza: Acribia.

Fietz, V. R., \& Salgado, J. M. (1999). Pectin and cellulose effects on cholesterol serum levels, and triglycerides in hiperlipidemic rats. Food Science and Technology (Campinas), 19(3), 318-321. http:// dx.doi.org/10.1590/S0101-20611999000300004.

Gao, Z. P., Yu, Z. F., Yue, T. L., \& Quek, S. Y. (2013). Adsorption isotherm, thermodynamics and kinetics studies of polyphenols separation from kiwifruit juice using adsorbent resin. Journal of Food Engineering, 116(1), 195-201. http://dx.doi.org/10.1016/j.jfoodeng.2012.10.037.

Geankoplis, C. J. (2003). Transport process and unit operations (4th ed.). New Delhi: Prentice Hall.

Hollebeeck, S., Borlon, F., Schneider, Y. J., Larondelle, Y., \& Rogez, H. (2013). Development of a standardised human in vitro digestion protocol based on macronutrient digestion using response surface methodology. Food Chemistry, 138(2-3), 1936-1944. http://dx.doi. org/10.1016/j.foodchem.2012.11.041. PMid:23411328.

Lebet, V., Arrigoni, E., \& Amado, R. (1998). Digestion procedure using mammalian enzymes to obtain substrates for in vitro fermentation studies. Lebensmittel-Wissenschaft \& Technologie, 31(6), 509-515. http://dx.doi.org/10.1006/fstl.1998.0402.

Lehninger, A. L., \& Nelson, K. Y. (2006). Princípios de bioquímica (4th ed.). São Paulo: Sarvier.

Li, A., Zhang, Q., Zhang, G., Chen, J., Fei, Z., \& Liu, F. (2002). Adsorption of phenolic compounds from aqueous solutions by a water-compatible 
hypercrosslinked polymeric adsorbent. Chemosphere, 47(9), 981-989. http://dx.doi.org/10.1016/S0045-6535(01)00222-3. PMid:12108706.

Maegawa, Y., Sugino, K., \& Sakurai, H. (2007). Identification of free radical species derived from caffeic acid and related polyphenols. Free Radical Research, 41(1), 110-119. http://dx.doi.org/10.1080/10715760600943892. PMid:17164184.

Manach, C., Scalbert, A., Morand, C., Rémésy, C., \& Jiménez, L. (2004). Polyphenols: food sources and bioavailability. The American Journal of Clinical Nutrition, 79(5), 727-747. PMid:15113710.

Marlett, J. A. (1992). Content and composition of dietary fiber in 117 frequently consumed foods. Journal of the American Dietetic Association, 92(2), 175-186. PMid:1310700.

McCabe, W. L., Smith, J. C., \& Harriott, P. (2005). Unit operations of chemical engineering (7th ed.). Boston: McGrall Hill.

Mekoue Nguela, J., Sieczkowski, N., Roi, S., \& Vernhet, A. (2015). Sorption of grape proanthocyanidins and wine polyphenols by yeasts, inactivated yeasts, and yeast cell walls. Journal of Agricultural and Food Chemistry, 63(2), 660-670. http://dx.doi.org/10.1021/ jf504494m. PMid:25575250.

Minekus, M., Marteau, P., Havenaar, R., \& Huis in’t veld, J. H. J. (1995). A multicompartmental dynamic computer-controlled model stimulating the stomach and small intestine. Alternatives to Laboratory Animals, 23, 197-209.

Mullie, P., Clarys, P., Deriemaeker, P., \& Hebbelinck, M. (2007). Estimation of daily human intake of food flavonoids. Plant Foods for Human Nutrition, 62(3), 93-98. http://dx.doi.org/10.1007/s11130007-0047-7. PMid:17597415.

Mwangi, I. W., Ngila, J. C., Ndung'u, P., \& Msagati, T. A. M. (2014). Removal of phenolics from aqueous media using quaternised maize tassels. Journal of Environmental Management, 134(1), 70-79. http:// dx.doi.org/10.1016/j.jenvman.2013.12.031. PMid:24463851.

Oliveira, D. M., \& Bastos, D. H. M. (2011). Biodisponibilidade de ácidos fenólicos. Quimica Nova, 34(6), 1051-1056. http://dx.doi. org/10.1590/S0100-40422011000600023.

Oliveira, G. I., Jr., Costa, N. M. B., Martino, H. S. D., \& Paes, M. C. D. (2014). Chemical composition and effects of micronized corn bran on iron bioavailability in rats. Food Science and Technology (Campinas), 34(3), 616-622. http://dx.doi.org/10.1590/1678-457x.6330.

Padilha, M. P., Campos, J. T. S., Moreira, J. C., \& Federici, C. C. (1995). Estudo das propriedades de troca iônica e/ou da adsorção da celulose e celuloses modificadas. Quimica Nova, 18(6), 529-533.

Pereira, M. A., O’Reilly, E., Augustsson, K., Fraser, G. E., Goldbourt, U., Heitmann, B. L., Hallmans, G., Knekt, P., Liu, S., Pietinen, P., Spiegelman, D., Stevens, J., Virtamo, J., Willett, W. C., \& Ascherio, A. (2004). Dietary fiber and risk of coronary heart disease: a pooled analysis of cohort studies. Archives of Internal Medicine, 164(4), 370376. http://dx.doi.org/10.1001/archinte.164.4.370. PMid:14980987.

Pillai, S. S., Deepa, B., Abraham, E., Girija, N., Geetha, P., Jacob, L., \& Koshy, M. (2013). Biosorption of Cd(II) from aqueous solution using xanthated nano banana cellulose: equilibrium and kinetic studies. Ecotoxicology and Environmental Safety, 98(1), 352-360. http://dx.doi.org/10.1016/j.ecoenv.2013.09.003. PMid:24091040.

Pompeu, D. R., Moura, F. G., Silva, E. M., \& Rogez, H. (2010). Equilibria, kinetics, and mechanisms for the adsorption of four classes of phenolic compounds onto synthetic resins. Separation Science and Technology, 45(5), 700-709. http://dx.doi.org/10.1080/01496390903562274.

Ribeiro, M. H. L., Silveira, D., \& Ferreira-Dias, S. (2002). Seletive adsorption of limonin and naringin from orange juice to natural and synthetic adsorbents. European Food Research and Technology, 215(6), 462-471. http://dx.doi.org/10.1007/s00217-002-0592-0.

Robards, K., Prenzler, P. D., Tucker, G., Swatsitang, P., \& Glover, W. (1999). Phenolic compounds and their role in oxidative processes in fruit. Food Chemistry, 66(4), 401-436. http://dx.doi.org/10.1016/ S0308-8146(99)00093-X.

Silberberg, M., Morand, C., Mathevon, T., Besson, C., Manach, C., Scalbert, A., \& Remesy, C. (2006). The bioavailability of polyphenols is highly governed by the capacity of the intestine and of the liver to secrete conjugated metabolites. European Journal of Nutrition, 45(2), 88-96. http://dx.doi.org/10.1007/s00394-005-0568-5. PMid:15981077.

Skoog, D. A., Holler, F. J., \& Crouch, S. R. (2007). Principles of instrumental analysis (6th ed.). Belmont, CA: Thomson Brooks/Cole.

Souza, J. N. S., Silva, E. M., Loir, A., Rees, J. F., Rogez, H., \& Larondelle, Y. (2008). Antioxidant capacity of four polyphenol-rich Amazonian plant extracts: a correlation study using chemical and biological in vitro assays. Food Chemistry, 106(1), 331-339. http://dx.doi. org/10.1016/j.foodchem.2007.05.011.

Srivastava, V. C., Swamy, M. M., Mall, I. D., Prasad, B., \& Mishra, I. M. (2006). Adsorptive removal of phenol by bagasse fly ash and activated carbon: equilibrium, kinetics and thermodynamics. Colloids and Surfaces A: Physicochemical and Engineering Aspects, 272(1-2), 89-104. http://dx.doi.org/10.1016/j.colsurfa.2005.07.016.

StatSoft Inc. (2006). STATISTICA Kernel Release 7.1 software. Tulsa, OK: StatSoft Inc.

Strachowski, P., \& Bystrzejewski, M. (2015). Comparative studies of sorption of phenolic compounds ontocarbon-encapsulated iron nanoparticles, carbon nanotubesand activated carbon. Colloids and Surfaces A: Physicochemical and Engineering Aspects, 467(2), 113123. http://dx.doi.org/10.1016/j.colsurfa.2014.11.044.

Teixeira, V. G., Coutinho, F. M. B., \& Gomes, A. S. (2001). The most important methods for the characterization of porosity of styrenedivinylbenzene based resin. Quimica Nova, 24(6), 808-818.

Treybal, R. E. (1980). Mass-transfer operations (3rd ed.). Singapore: McGraw-Hill.

Tungland, B. C., \& Meyer, D. (2002). Nondigestible oligo- and polysaccharides (dietary fiber): their physiology and role in human health and food. Comprehensive Reviews in Food Science and Food Safety, 1(3), 90-109. http://dx.doi.org/10.1111/j.1541-4337.2002. tb00009.x.

Turley, S. D., Daggy, B. P., \& Dietschy, J. M. (1991). Cholesterol-lowering action of psyllium mucilloid in the hamster: sites and possible mechanisms of action. Metabolism: Clinical and Experimental, 40(10), 1063-1073. http://dx.doi.org/10.1016/0026-0495(91)90131-F. PMid:1943733.

Watanabe, S., Inoue, N., Imai, K., Suemaru, K., Araki, H., \& Aimoto, T. (2006). Interaction of drugs with dietary fibre - adsorption of drugs onto dietary fibre in in vitro study. Japanese Journal of Pharmaceutical Health Care and Sciences, 32(3), 221-226. http:// dx.doi.org/10.5649/jjphcs.32.221.

Weber, W. J. (1972). Physicalchemical processes for water quality control. New York: Wiley.

Wu, L., Melton, L. D., Sanguansri, L., \& Augustin, M. A. (2014). The batch adsorption of the epigallocatechin gallate onto apple pomace. Food Chemistry, 160(10), 260-265. http://dx.doi.org/10.1016/j. foodchem.2014.03.098. PMid:24799237. 